\title{
Correction: A human Myogenin promoter modified to be highly active in alveolar rhabdomyosarcoma drives an effective suicide gene therapy
}

\author{
Johanna Pruller • Isabella Hofer • Massimo Ganassi $\mathbb{B} \cdot$ Philipp Heher $\cdot$ Michelle T. Ma $(\mathbb{D} \cdot$ Peter S. Zammit $(\mathbb{D}$
}

Published online: 11 November 2020

(c) The Author(s) 2020. This article is published with open access

Correction to: Cancer Gene Therapy

https://doi.org/10.1038/s41417-020-00225-0

published online 25 September 2020

This Article was originally published with an incorrect title: "A modified human Myogenin promoter that is highly active in alveolar rhabdomyosarcoma" instead of "A human Myogenin promoter modified to be highly active in alveolar rhabdomyosarcoma drives an effective suicide gene therapy". This has now been corrected in both the PDF and HTML versions of the Article.

\begin{abstract}
Open Access This article is licensed under a Creative Commons Attribution 4.0 International License, which permits use, sharing, adaptation, distribution and reproduction in any medium or format, as long as you give appropriate credit to the original author(s) and the source, provide a link to the Creative Commons license, and indicate if changes were made. The images or other third party material in this article are included in the article's Creative Commons license, unless indicated otherwise in a credit line to the material. If material is not included in the article's Creative Commons license and your intended use is not permitted by statutory regulation or exceeds the permitted use, you will need to obtain permission directly from the copyright holder. To view a copy of this license, visit http://creativecommons. org/licenses/by/4.0/.
\end{abstract}

